\title{
Consumer preference for apples: the role of attributes influencing the choice and consumption
}

\author{
Racskó, J. ${ }^{1}$, Miller, D.D. ${ }^{1}$, Duarte, E.E. ${ }^{2}$, Szabó, Z. ${ }^{3}$, Soltész, M. ${ }^{3}$ \& Nyéki, J. ${ }^{3}$ \\ ${ }^{\prime}$ Department of Horticulture and Crop Science, The Ohio State University/OARDC, 1680 Madison Avenue, \\ Wooster, OH-44691, USA, Email: racsko.1@osu.edu \\ ${ }^{2}$ Department of Food Sciences, Purdue University, 745 Agriculture Mall Drive, West Lafayette, IN, USA, \\ Email: eduarteg@purdue.edu \\ ${ }^{3}$ Institute for Research and Development, University of Debrecen, 138 Boszormenyi St., Debrecen, 4032, Hungary, \\ Email:erdodine@agr.unideb.hu
}

Summary: Consumers consider good quality fruits to be those that look good, are firm and offer good flavour and nutritive value. Nowadays, consumers are, however, increasingly interested in food qualities which cannot be discovered by looking, tasting or smelling the products but their roles are not yet really cleared up. Therefore, the objective of this study was to explore the importance of selected kinds of attributes (taste, size, colour, cultivar, origin and price) influencing the choice of apples of customers. In accordance with several authors, fruit qualities (taste, size and colour) seemed to be the major attributes influencing the choice of apple independently of people's age and gender. However, the size of fruit had lower importance with increased age. Generally, females gave higher importance ratings for most attributes than did males. The price was getting more important for consumer's choice with age which can be connected with their socioeconomic situation. The origin of fruit and the cultivar did not have important influence on consumer's choice. Authors also investigated the preference of consumers for six selected apple varieties ('Jonagold', 'Idared', 'Royal Gala', 'Golden Reinders', 'Braeburn', and 'Granny Smith'), and pointed out the role of the origin in fruit quality and in choice of apple in the case of 'Granny Smith' cultivar. Apple fruit samples from Austria, Argentina, Chile, Hungary and South Africa were involved in this study. Authors evaluated fruit quality parameters of above cultivars and compared them to consumer preference. Consumer preference usually represented the quality attributes of the fruit well. It is also concluded that degree of liking of apple cultivars varies through gender and age. Children and young consumers preferred 'Royal Gala', 'Granny Smith' and 'Braeburn', mostly. In spite of 'Idared' is one of the cultivars grown on the largest area in Hungary, the lowest preference ratings were given for it in both gender categories. Middle-aged consumers (between 25 and 50 years of age) preferred crispy apples with red or blemished skin color ('Royal Gala', and 'Jonagold'). 'Jonagold' and 'Idared' were the most preferred cultivars for the consumers above the age of 50 likely because of their relatively low price, as price plays a significant influencing role in the purchase of these consumers. The relatively expensive and soury 'Granny Smith' appeared not really preferred by this age group. In spite of the significant differences in instrumentally measured fruit quality parameters among 'Granny Smith' fruit samples from different countries, consumers did not give significantly different preference rating scores for those.

Key words: gender, age, fruit quality, food habit, price, cultivar, country of origin

\section{Introduction}

Fruit quality can be defined in a number of ways. The attributes included in the concept of quality depend largely on who is making the definition (Wandel \& Bugge, 1997). Consumers consider good quality fruits to be those that look good, are firm and offer good flavour and nutritive value (Kader, 2002). Consumers are also interested in many other aspects related to fruit quality such as food safety and health (Schafer et al., 1993; Holb, 2005; Racskó et al., 2007; Kirchhoff et al., 2008). Conventional quality properties such as above taste and freshness, as well as nutritional quality, are related to personal interests. Although consumers buy on the basis of appearance and textural quality, their satisfaction and repeat purchases are dependent upon good eating quality (Kader, 2002). The purchase of a visually attractive fruit, which after a single bite is unacceptable, is a compelling reason for the 'buyer to beware' and to discourage future purchases (Redgwell \& Fischer, 2002). There are several psychological theories of how consumers react when their expectations of a product are not met (Deliza \& MacFie, 1996).

Nowadays, consumers are increasingly interested in food qualities which cannot be discovered by looking, tasting or smelling the products (Schafer et al., 1993; Wandel, 1994). Such quality attributes are related to the hygienic standards of food and the status with regard of rests of agrochemicals, as well as to the contamination from environmental pollution (Wandel \& Bugge, 1997). Since a large body of epidemiological evidence has been reported regarding the possible preventive effects of fruit consumption for several kinds of cancer and cardiovascular disease, fruits are considered to be 
a part of a healthy diet (Block et al., 1992; Gerster, 1991; Brug et al., 1995; Stanton, 2008; Brown \& Brown, 2008). While health is a motivating factor for purchasing fruit, there are many reasons why a high proportion of people do not meet recommended daily intakes. These include socioeconomic and social factors in the major part (Ferguson \& Boyd, 2002; Racskó et al., 2007).

Several authors investigated the consumer preferences finding such as the cultivar differences (Dailland-Spinnler et al., 1996; Jaeger et al., 1998; Kókai et al., 1998), consumers' age (Kühn \& Thybo, 2001; Рéneau et al., 2006), gender (Péneau et al., 2006), nationality (Racskó, 2007), fruit texture (Fillion \& Kilcast, 2002) mealiness (Jaeger et al., 1998) and/or price (Market Review, 1996; Racskó et al., 2007) to be important for the preferences. Other attributes seem to have negative impact on consumer choice such as the origin from import, GMO and one year cold stored (Kirchhoff et al., 2008). A questionnaire completed as a part of a consumer study collected data about the consumers, their attitudes and their eating and buying habits, thereby providing the background information for the marketing strategy (Poelman, 2008). Therefore, the objective of this study is to explore the importance of selected kinds of attitudes influencing the choice of apples of Hungarian consumers.

\section{Materials and Methods}

\section{Consumer tests}

The consumer tests were carried out at the Institute for Research and Development, University of Debrecen, Hungary during 2006-2008, monthly. Consumers were recruited from the local elementary and secondary schools and from the University of Debrecen. The evaluation involved 644 consumers in total. Among the 644 Hungarian consumers, the age distribution was 256 under the age 25 , 286 between ages 25 and 50 , and 102 above the age 50 . The gender distribution was as follows: 303 male and 341 female. In the same time, 15-20 consumers attended each session with an assistant who supervised the test. Every session was carried out between 3.00 and 6.00 p.m. to avoid significant preference shift within time of day (Birch et al., 1984 in Kühn \& Thybo, 2001). The consumer test consisted of a questionnaire that was presented on a paper sheet. The questionnaire was divided into 3 parts from which, in the first part, the following question was asked: 'How important are the following attributes in your choice of apple?'

$\begin{array}{ll}\text { i. } & \text { size } \\ \text { ii. } & \text { colour } \\ \text { iii. } & \text { taste } \\ \text { iv. } & \text { cultivar } \\ \text { v. } & \text { origin } \\ \text { vi. } & \text { price }\end{array}$

In the second part, participants were asked about their cultivar preference and in the third part they compared the acceptance for fruit of the same cultivar grown in different countries. Neither in the second nor in the third part of the session, consumers were not informed about the names of the cultivars used in the taste testing. Five-point importance scales were used for all attributes, for measuring cultivar preference and the role of the origin. Each point was labeled with a number from 1 to 5 and anchor points were additionally presented with verbal labels (1-not at all important, 5-very important). After collecting data, participants were asked about their age and gender.

\section{Apple samples}

Apples were randomly bought from Hungarian groceries and supermarkets (Tesco, Cora, Interspar, Lidl, Metro, Auchan) on the same day when the taste testings were held. All apples were of standard commercial size and color for the Hungarian market. In total, six apple cultivars were selected from markets: 'Jonagold', 'Idared', 'Royal Gala', 'Golden Reinders', 'Braeburn', and 'Granny Smith'. To evaluate the role of the origin in fruit quality and in consumer preference, 'Granny Smith' was selected from five countries. Fruit samples were came from Chile, Austria, Hungary, South Africa and Argentina.

\section{Fruit quality measurements}

The following fruit quality parameters were measured: fruit weight (FW, g), fruit diameter (DI, mm), soluble solids content (SSC, \%), flesh firmness (FF, $\mathrm{kg} \mathrm{cm}^{-2}$ ) and skin color (CO, \%). Fruit mass was weighed with a digital scale and diameter with a digital caliper. Soluble solids content was determined using Atago PAL-1 digital handheld refractometer (Atago Co., Japan). Fruit flesh firmness was measured on pared flesh with Fruit Tester FT 327 handheld penetrometer (Renato Lusa \& C. Snc, Ravenna, Italy) using a tip with a diameter of $11.1 \mathrm{~mm}$. Skin color percentage was determined visually and expressed as a rate of the blemished area of the total fruit surface.

\section{Data analyses}

Data analysis for preference data was performed using SPSS for Windows (Release 14., SPSS Inc., Chicago, USA), figures were prepared by Microsoft Office Excel for Windows (Release 2007., Microsoft Corp., USA). Statistical significance was defined at $p<0.05$ level. To compare the importance of the different attributes for apple choice, repeated measures analyses of variance (ANOVA) with the different attributes as levels of the within-subject factor were performed.

\section{Results and discussions}

\section{Attributes influencing the choice of apples}

Importance ratings of attributes for choice of apples of Hungarian consumers are presented in Figs. 1-3. Gender and age influenced the choice strongly as were observed by $\mathrm{Nu}$ et al. (1996), Helgesen et al. (1997) and Zandstra \& de Graaf 
(1998). In our examinations, age affected the choice of apples stronger than gender did. This contrasts with Péneau et al. (2006) observations, who carried out a similar research in order to clear up the attributes influencing the choice of apples of Swiss consumers. The order of the major factors influenced the choice were the taste, aroma and freshness in all of their eight age groups. The most important attribute for Hungarian consumers under the age 25 was the taste followed by fruit size and colour (Figure I). Thus, the choice of apples of young people was greatly influenced by fruit quality parameters. Quality parameters played a major role in Australian consumer purchase decisions of a specific apple in a survey of Kirchhoff et al. (2008), too. Clydesdale (1993) also drawn attention to the role of fruit colour. The importance of above three attributes were not significantly different from each other. No significant differences were found between the importance ratings given by men and women. Lower importance was characterised by the cultivar, price and origin, in this order. Females gave higher importance ratings than males for price and origin, the differences, however, were not significant.

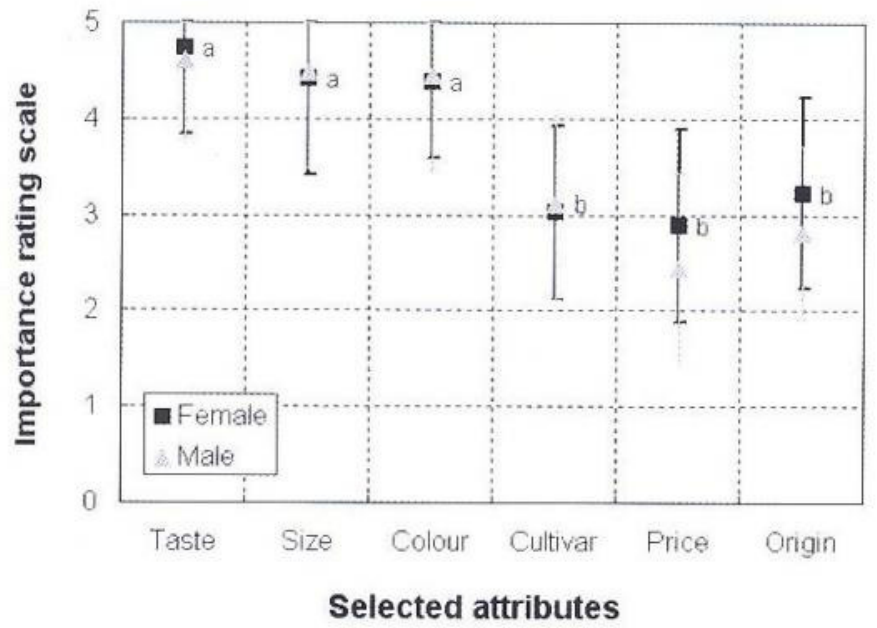

Figure 1 The attributes influencing the choice of apples for Hungarian male and female consumers under the age 25 (mean values with standard deviations, $N=644$ ). Different letters indicate significant differences among the mean values of attributes given by males and females $(p<0.05)$,

Fruit and vegetable consumption of young people was investigated by several authors, most of those dealt with a comparison of consumption and perception of individual vegetables and fruits in relation to e.g. social aspect and food habits (Keim et al., 1997; Baxter et al., 2000). In Danemark, Kühn \& Thybo (2001) supported Moskowitz (1994) experiences on apple preferences, that is using adults as consumers cannot be used to predict children's preference of apples. In Switzerland, the above mentioned Péneau et al. (2006) evaluated the following attributes: taste, aroma, freshness, appearance, cultivar, origin and fruit size. The took the amount of apples eaten per week into consideration, too, and made eight age groups of consumers. In the comparison of the Hungarian and Swiss consumers, the choice of apples of both of those nationals is mostly influenced by the taste. In Germany, the choice of fruits was greatly affected by their freshness $(A g V, 1981)$. Similar observations supported this establishment by Zind
(1989) on American consumers and by Ragaert et al. (2004). They found that ripeness and taste of fruit are also very important. In the experiments of Wandel \& Bugge (1997) and Babicz-Zielsinska \& Zagorska (1998), the taste, freshness and appearance were the most important. Fillion \& Killcast (2002) stressed, however, the crispness of the fruit. Others even paid attention to the importance of the cultivar (Jaeger et al., 1998; Andani et al., 1998 and Kókai et al., 1998). Dalliant-Spinnler et al. (1996) and Stow (1995) found that the taste and the consistency of the flesh are the most important. The mealiness of the apple flesh and other sensory characteristics like spongy texture and negative flavour attributes influenced consumer preference negatively (Jaeger et al., 1998).

In our experiment, the attributes influenced the choice of apple were changed with age. Consumers between the ages 25 and 50 percieved the fruit quality parameters in the same order as the children did (Figure 2). Interestingly, the price became also conspicuous at the same significant level as the taste, fruit size and colour. In contrary, in a market research conducted for ENZA, the marketing organization for New Zealand apples in the UK, has shown that nearly $80 \%$ of UK consumers consider quality more important than price (Market Review, 1996). The reason of the difference can be found in socioeconomical factors of these countries (Ferguson \& Boyd, 2002). This is in accordance with Brug et al. (1995) who found in the Netherlands that social influence and financial costs were important environmental aspects in choice of fruit. Latter was a barrier but seemed to be dependent on seasonal variations in availability. Their respondants stated that food items such as fruits were not bought when they are too expensive according to their judgement. This was observed in our study where Hungarian pensioners definitely do not be able to buy farimported apples such as 'Red Delicious' from Argentina, 'Granny Smith' from Chile or South Africa, or fruit of expensive cultivars such as 'Pink Lady' which generally have 2-4 times higher prices than Hungarian ones do.

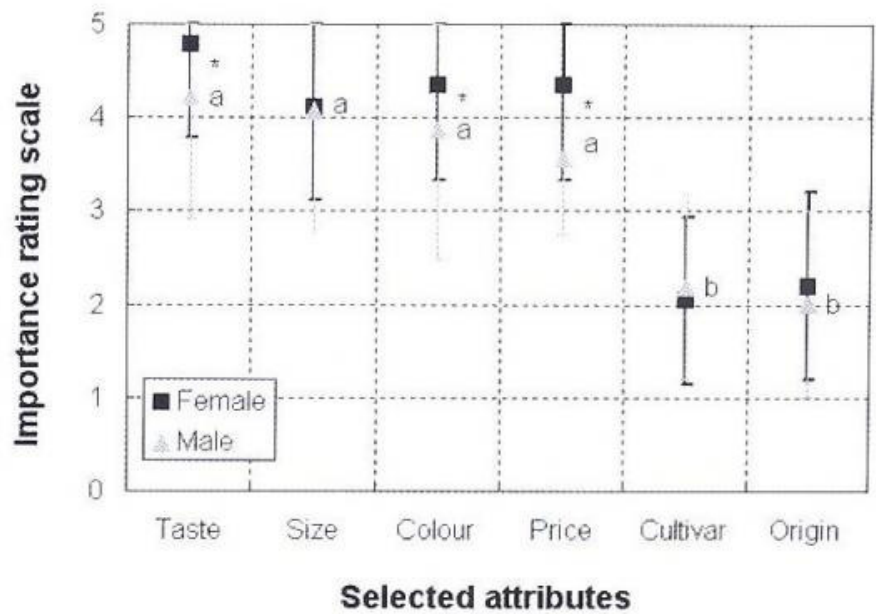

Figure 2 The attributes influencing the choice of apples for Hungarian male and female consumers between the ages 25 and 50 (mean values with standard deviations, $N=644$ ). Different letters indicate significant differences among the mean values of attributes given by males and females $(p<0.05)$. Asterisks represent significant differences between male and female importance ratings at $p<0.05$ level. 
For all above four attributes, females gave higher importance ratings. Cultivar and origin did not play important role in the choice, where no significant differences were found between men and women. In contrast, the choice of apples of Swiss middle-aged consumers (between the ages 30 and 50) was still mostly influenced by the taste, aroma and freshness. The importance of the origin of apples (from organic production) played also a role in the choice. The choice of apples of the Hungarian consumers above the age 50 was greatly influenced by the taste and price (Figure 3). This apparently shows the unfavourable social conditions of the Hungarian pensioners. The size of fruit had lower importance with increased age. No significant differences were found among fruit size, origin and cultivar attributes. The gender played significant role in the taste and price attributes; females gave higher importance ratings for all of those. For origin, male consumers indicated higher importance, without any significant difference.

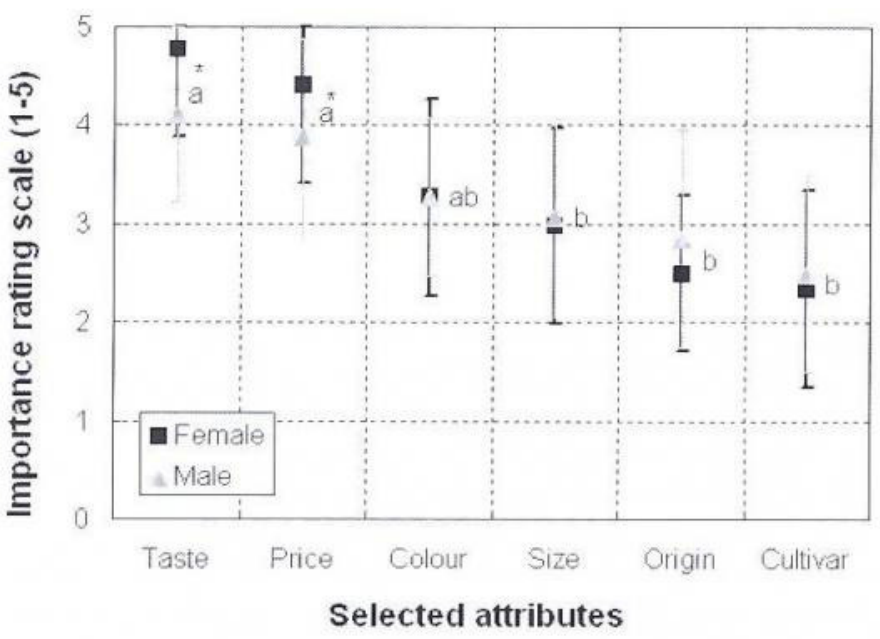

Figure 3 The attributes influencing the choice of apples for Hungarian male and female consumers above the age 50 (mean values with standard deviations, $N=644$ ). Different letters indicate significant differences among the mean values of attributes given by males and females $(p<0.05)$. Asterisks represent significant differences between male and female importance ratings at $p<0.05$ level.

\section{Cultivar preference}

Fruit quality parameters of the examined apple cultivars are shown in Table 1. Excellent fruit quality was measured for 'Jonagold', 'Golden Reinders' and for 'Royal Gala' in all years. The cultivar preferences of the Hungarian consumers are presented on the Figures 4-6. Children and young consumers preferred 'Royal Gala', 'Granny Smith' and 'Braeburn' cultivars, mostly. Similar results were found by Kühn \& Thybo (2001) with 9-13 years old consumers where 'Gala' and 'Gloster' cultivars had significantly the highest preference ratings by appearance. 'Elstar', 'Jonagold' and 'Gala' cultivars were the best by taste. In our experiment, 'Golden Reinders' had also a high preference rating, without any significant difference between men and women. In spite of 'Idared' is one of the cultivars grown at the largest area in Hungary, the lowest preference ratings were given for it in both gender categories. However, it is important to note that preferences of young consumers such as children are strongly influenced by what cultivars are served in their parents' homes (Criner, 1994).

Table 1 Fruit quality parameters of selected apple cultivars (average of 2006-2008)

\begin{tabular}{|l|c|c|c|c|c|c|}
\hline Parameter & Braeburn & $\begin{array}{c}\text { Golden } \\
\text { Reinders }\end{array}$ & $\begin{array}{c}\text { Granny } \\
\text { Smith }\end{array}$ & Idared & Jonagored & $\begin{array}{c}\text { Royal } \\
\text { Gala }\end{array}$ \\
\hline Fruit weight & $175,5 \mathrm{~b}$ & $196,5 \mathrm{a}$ & $164, \mathrm{c}$ & $174 \mathrm{~b}$ & $201,6 \mathrm{a}$ & $163,9 \mathrm{c}$ \\
\hline Diameter & $74,8 \mathrm{a}$ & $76,4 \mathrm{a}$ & $72,9 \mathrm{~b}$ & $75,3 \mathrm{ab}$ & $76,8 \mathrm{a}$ & $71,2 \mathrm{~b}$ \\
\hline Height & $65,8 \mathrm{~b}$ & $71,1 \mathrm{a}$ & $67,1 \mathrm{ab}$ & $64 \mathrm{~b}$ & $68,4 \mathrm{a}$ & $64,8 \mathrm{~b}$ \\
\hline Shape index & 0,88 & 0,93 & 0,92 & 0,85 & 0,89 & 0,91 \\
\hline Flesh firmness & $103,6 \mathrm{a}$ & $68,8 \mathrm{~b}$ & $101,4 \mathrm{a}$ & $74,2 \mathrm{~b}$ & $71,2 \mathrm{~b}$ & $94,1 \mathrm{ab}$ \\
\hline Skin colour & $59,7 \mathrm{a}$ & $0 \mathrm{~b}$ & $1,3 \mathrm{~b}$ & $72,7 \mathrm{a}$ & $61,1 \mathrm{a}$ & $75,6 \mathrm{a}$ \\
\hline Dry matter & $14,9 \mathrm{a}$ & $14,7 \mathrm{a}$ & $13,8 \mathrm{~b}$ & $14,2 \mathrm{ab}$ & $14 \mathrm{~b}$ & $13,9 \mathrm{~b}$ \\
\hline
\end{tabular}

Jaeger et al. (1998) evaluated the consumer preference for three apple cultivars and found that British and Danish consumers preferred 'Cox Orange Renet' and 'Jonagold', mostly. In Hungary, middle-aged consumers (between 25 and 50 years of age) preferred crispy apples with red or blemished skin color ('Royal Gala', 'Jonagold'). Male consumers gave significantly higher preference ratings for 'Idared' than females. The same observations were made on 'Granny Smith'. 'Golden Reinders' is still in the favoured cultivars proved by its average preference ratings above 4 . The liking of 'Golden Reinders' in Hungary was also found by Kókai et al (1998) who observed its higher preference ratings compared to 'Gloster', 'Jonagold' and 'Mutsu'. The oldest age group (above 50 years) preferred the red-colored 'Jonagold', 'Idared' and 'Royal Gala', mostly (Figure 6). Significant difference was found between male and female consumers concerning the preference for 'Idared'; male consumers preferred this cultivar at a significantly higher level then females. Jonagold' and 'Idared' were the most

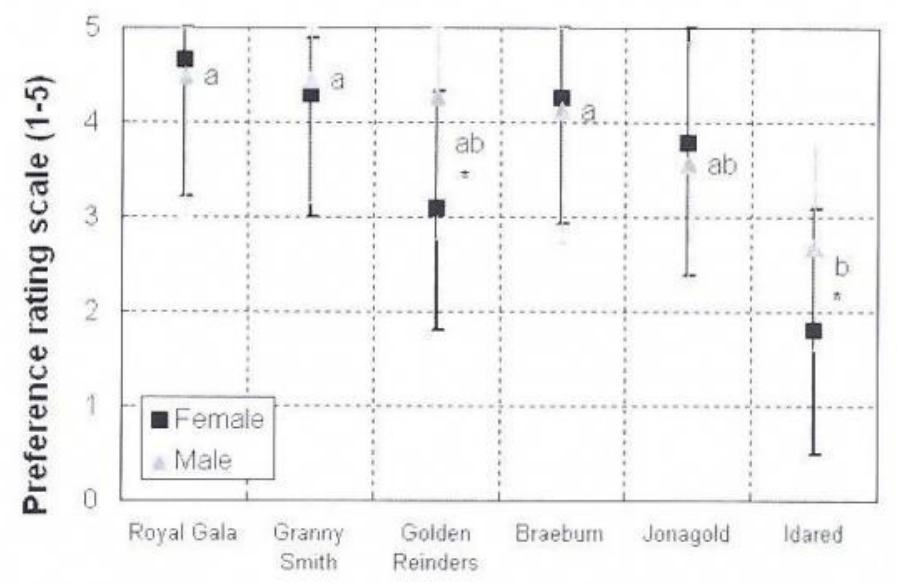

Selected cultivars

Figure 4 Cultivar preference of Hungarian male and female consumers under the age 25 (mean values with standard deviations, $N=644$ ). Different letters indicate significant differences among the mean values of attributes given by males and females $(p<0.05)$. Asterisks represent significant differences between male and female importance ratings at $p<0.05$ level. 
preferred cultivars for the consumers above the age of 50 likely because of their relatively low price, as price plays a significant influencing role in the purchase of these consumers. This is agreement with the fact that there is an evidence for substitution and complimentarity in consumer purchase decisions among cultivars (Richards, 1999; Patterson \& Richards, 2000; Richards \& Patterson, 2000). For example, an increase in price of 'Fuji' apples will result in a reduction in consumer demand for 'Fuji' and an increase in demand for 'Golden Delcious' (Harker et al., 2003). In this study, the relatively expensive 'Granny Smith' appeared not really preferred by this age group partly because of the green colour and soury taste. In contrary, Zandstra \& de Graaf (1998) found that the aversion to sourness decreased with increased age. 'Golden Reinders' and 'Braeburn' were at a significantly lower preference level than at that of 'Jonagold', 'Idared' and 'Royal Gala'.

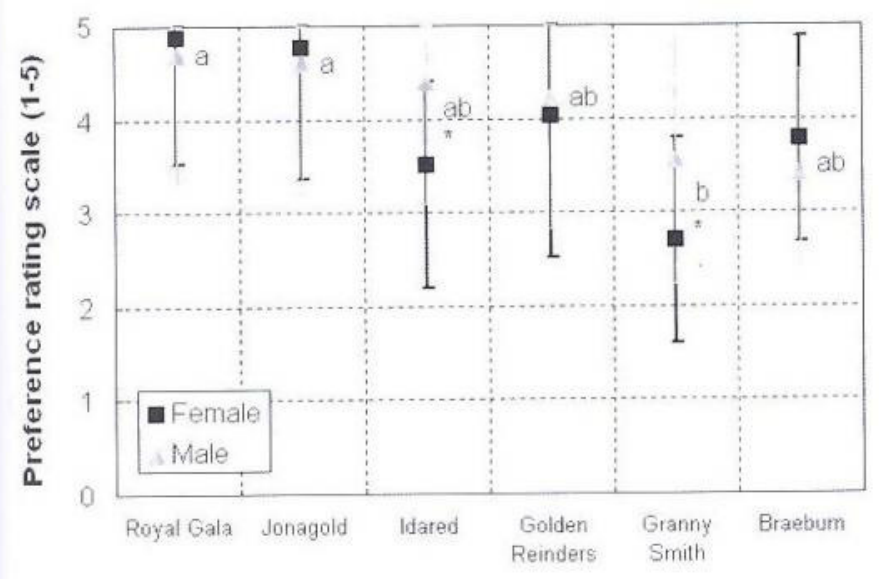

Selected cultivars

Figure 5 Cultivar preference of Hungarian male and female consumers between the ages 25 and 50 (mean values with standard deviations, $N=644$ ). Different letters indicate significant differences among the mean values of attributes given by males and females $(p<0.05)$. Asterisks represent significant differences between male and female importance ratings at $p<0.05$ level.

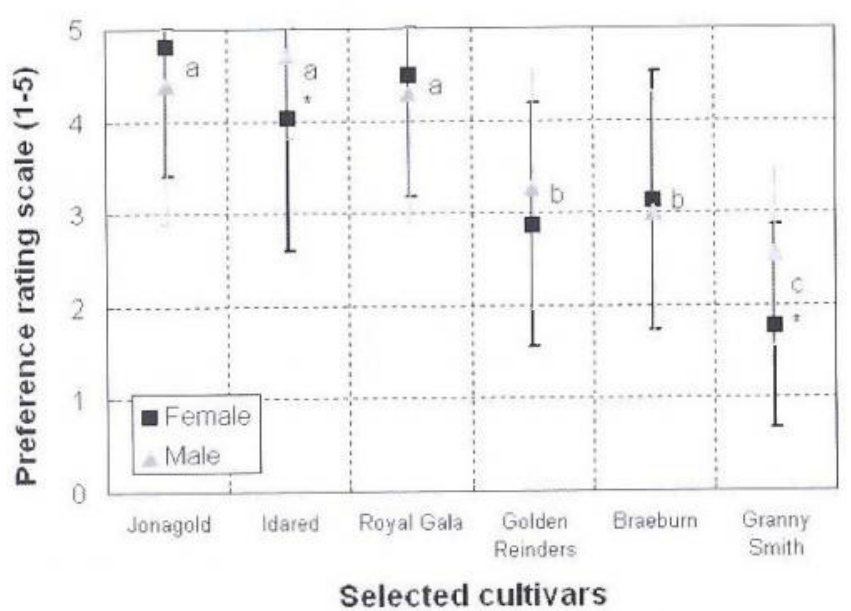

Figure 6 Cultivar preference of Hungarian male and female consumers above the age 50 (mean values with standard deviations, $N=644$ ). Different letters indicate significant differences among the mean values of attributes given by males and females $(p<0.05)$. Asterisks represent significant differences between male and female importance ratings at $p<0.05$ level.

\section{The role of the country of origin in the fruit quality and choice of apple}

There were significant differences in fruit quality among fruits came from different countries for the selected 'Granny Smith' cultivar (Table 2). Fruit of the Chilean samples had the biggest size (weight, diameter and height). The smallest fruit came from South Africa. There were no significant differences in flesh firmness among fruit samples originated from different countries. No important differences were found in skin colour among countries. The highest amount of dry matter was measured for the Chilean fruit.

Table 2 Fruit quality parameters of Granny Smith came from different countries (average of 2006-2008)

\begin{tabular}{|l|c|c|c|c|c|}
\hline Parameter & Argentine & Chilean & $\begin{array}{c}\text { South } \\
\text { African }\end{array}$ & Hungarian & Austrian \\
\hline Fruit weight & 160 & 185,4 & 147,4 & 158,9 & 167,8 \\
\hline Diameter & 72,7 & 762 & 70,6 & 71,8 & 73,2 \\
\hline Height & 64 & 70,9 & 60,7 & 66,8 & 67,3 \\
\hline Shape index & 0,88 & 0,93 & 0,86 & 0,93 & 0,92 \\
\hline Flesh firmness & 105,6 & 102,4 & 102,5 & 99,7 & 100,1 \\
\hline Skin colour & 0 & 0 & 2,9 & 1,8 & 0,5 \\
\hline Dry matter & 13,7 & 14,2 & 13,2 & 13,9 & 13,9 \\
\hline
\end{tabular}

There is a small number of information on how the country of origin influences the perception and purchasing behavior of apple consumers. In an interview with UK women, a quarter of participants at some point mentioned that they were motivated to buy British apples (Harker, 2001). The number of the literature sources on the consumer preference for the same cultivar came from different countries are also very limited. For 'Royal Gala', Racskó et al. (2007) pointed out the differences in fruit quality and in consumer preference for apple came from different climate zones (temperate zone, subtropics and tropics). Preference of

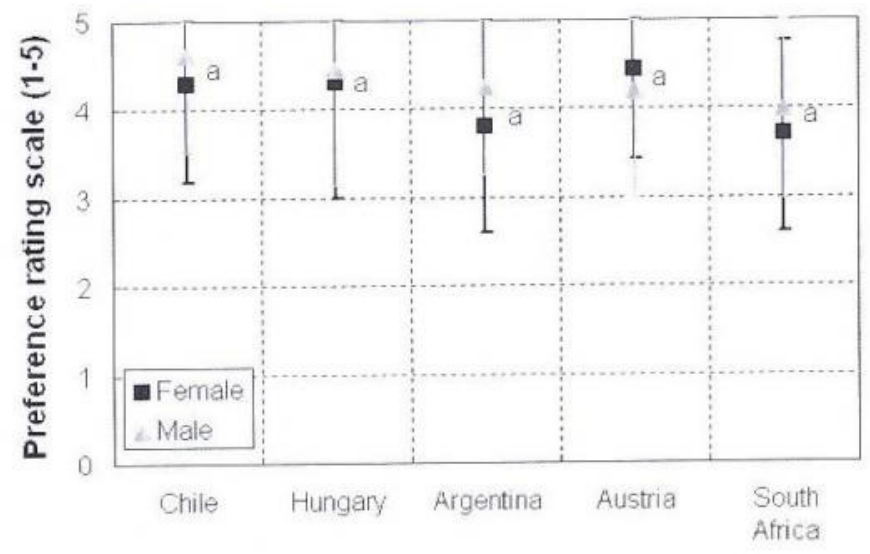

\section{Country origin}

Figure 7 The role of the country of origin in the preference for 'Granny Smith' apple for Hungarian male and female consumers under the age 25 (mean values with standard deviations, $N=644$ ). Different letters indicate significant differences among the mean values of attributes given by males and females $(p<0.05)$. 
the Hungarian consumers for 'Granny Smith' apple grown in different countries can be seen on Figures 7-9. The role of the age is conspicuous; the liking of this cultivar decreased with increased age. Any significant differences were not found between males and females under 25 years of age (Figure 7), but some were observed in the age groups of 25-50 and above 50 years. In contrary, with the previous results of Racskó et al. (2007) on 'Royal Gala', as there was not any significant difference in the preference rating scores among fruit samples, consumers could not perceive difference among 'Granny Smith' fruit came from different countries. The reason was partly the skin colour, because there were significant differences in skin colour of 'Royal Gala' fruits came from different countries and consumers are generally strongly influenced by the fruit appearance.

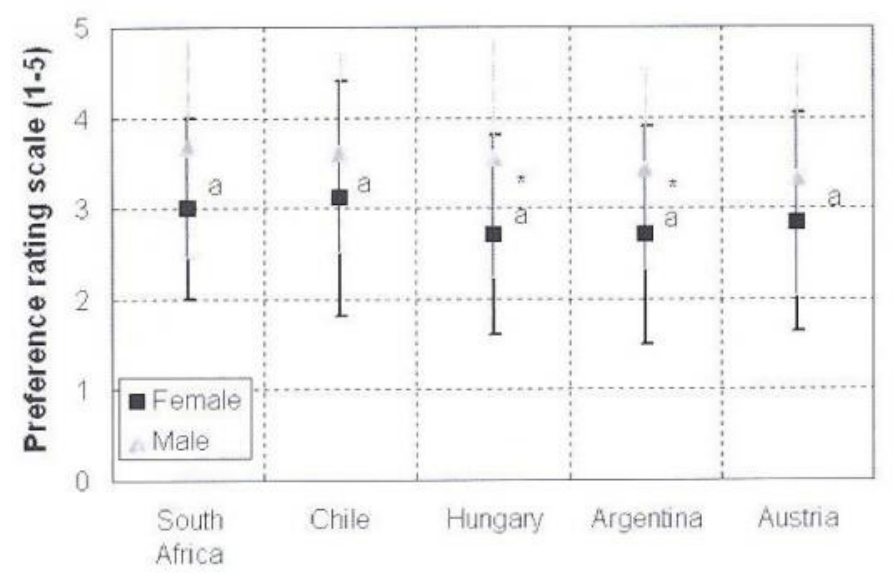

\section{Country origin}

Figure 8 The role of the country of origin in the preference for 'Granny Smith' apple for Hungarian male and female consumers between the ages 25 and 50 (mean values with standard deviations, $N=644$ ). Different letters indicate significant differences among the mean values of attributes given by males and females $(p<0.05)$. Asterisks represent significant differences between male and female importance ratings at $p<0.05$ level.

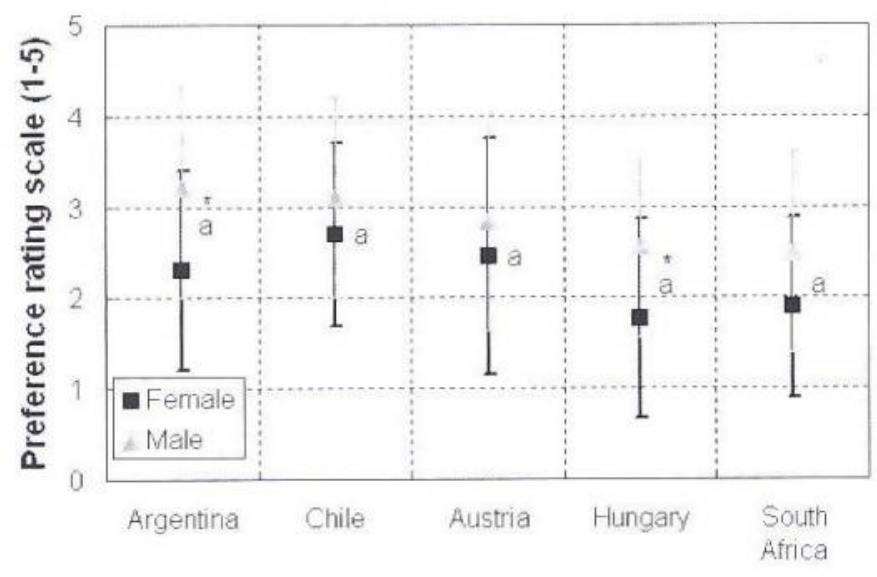

Country origin

Figure 9 The role of the country of origin in the preference for 'Granny Smith' apple for Hungarian male and female consumers above the age 50 (mean values with standard deviations, $N=644$ ). Different letters indicate significant differences among the mean values of attributes given by males and females $(p<0.05)$. Asterisks represent significant differences between male and female importance ratings at $p<0.05$ level.

\section{References}

AgV (1981): Verbraucherverhalten beim Lebensmitteleinkauf. Verbraucherpolitische Korrespondenz, Arbeitsgemeinschaft der Verbraucherverbände c. V., Bonn, 37a, pp. 1-28.

Babicz-Zielinska, E. \& Zagorska, A. (1998): Factors affecting the preferences for vegetables and fruits. Polish J. Food Nutr. Sci. 48(4): 755-762.

Baxter, I.A., Schröder, M.J.A. \& Bower, J.A. (2000): Childrens' perceptions of age preferences for vegetables in the west of Scotland: the role of demographic factors. J. Sensory Studies. 15: 361-381.

Birch, L.L., Billman, J. \& Richards, S.S. (1984): Time of day influences food acceptability. Appetite. 5: 109-116.

Block, G., Patterson, B. \& Subar, A. (1992): Fruit, vegetables, and cancer prevention: A review of the epidemiological evidence. Nutrition and Cancer. 18: 1-29.

Brown, G. \& Brown, J. (2008): The health benefits of fruit and vegetable consumption. Australian Fruitgrower. 2 (2): 14-15.

Brug, J., Debie, S., van Assema, P. \& Weijts, W. (1995): Psychosocial determinants of fruit and vegetable consumption among adults: results of focus group interviews. Food Quality and Preference. (6): 99-107.

Clydesdale, F.M. (1993): Color as a factor in food choice. Critical Reviews in Food Science and Nutrition. 33 (1): 83-101.

Criner, G.K., Kezis, A.S., Cheng, H.T. \& Nord, M. (1994): Young adult apple varietal preference : Socioeconomic factors, Northern New England. Product Development \& Marketing Center, University of Maine. Staff paper No. F.1. 007.

Daillant-Spinnler, B., MacFie, H.J.H., Beyts, P.K. \& Hedderley, D. (1996): Relationships between perceived sensory properties and major preference directions of 12 varieties of apples from the Southern hemisphere. Food Quality and Preference. 7 (2): 113-126.

Deliza, R. \& MacFie, H.J.H. (1996): The generation of sensory expectation by external cues and its effect on sensory perception and hedonic ratings: a review. J. Sensory Studies. 11 (2): 103-128.

Ferguson, I.B. \& Boyd, L.M. (2002): Inorganic nutrients and fruit quality (In: Knee, M. (ed.): Fruit quality and its biological basis.) Sheffield Academic Press, Sheffield, pp. 17-45.

Fillion, L. \& Kilcast, D. (2002): Consumer perception of crispness and crunchiness in fruits and vegetables. Food Quality and Preference (13): 23-29.

Gerster, H. (1991): Potential role of of beta-carotene in the prevention of cardiovascular disease. Int. J. Vitamin and Nutrition Res. (61): 277-291.

Harker, R. (2001): Consumer response to apples. Washington Tree Fruit Postharvest Conference, March 13-14, 2001, Wenatchee, WA. Available at http://postharvest.tfrec.wsu.edu/PC2001 V.pdf

Helgesen, H., Ragnhild, S. \& Naes, T. (1997): Consumer preference mapping of dry fermented lamb sausages. Food Quality and Preference. (8): 97-109.

Holb, I. (2005): Az ökológiai (bio-) és az integrált termesztés és növényvédelem alapelvei és kapcsolatuk. Nemzetközi (IFOAM) növényvédelmi elóírások. (In: Holb, I. (szerk.) A gyümölcsösök és a szôló ökológiai növényvédelme), Mezôgazda Kiadó, Budapest, pp. 11-17 és 18-28. 
Jaeger, S.R., Andani, Z., Wakeling, I.N. \& MacFie, H.J.H. (1998): Consumer preferences for fresh and aged apples: A crosscultural comparison. Food Quality and Preference 9 (5): 355-366.

Kader, A.A. (2002): Fruits in the global market In: Knee, M. (ed.): Fruit quality and its biological basis. Sheffield Academic Press, Sheffield, pp. 1-16.

Keim, K., Stewart, B. \& Voichick, J. (1997): Vegetable and fruit intake and perception of selected young adults. J. Nutr. Educ. (29): $80-85$.

Kirchhoff, S., Zeppa, A., Forrest, A. \& Smyth, H.E. (2008): Consumer drivers when selecting apples. Australian Fruitgrower. 2 (2): 16-17.

Kókai, Z., Sass, P., Sipos, B., Erdélyi, M. \& Ferenczy, A. (1998): Consumer preference tests on sensory quality of apple verieties. Kertészeti Egyetem Közleményei. (57): 5-11.

Kühn, B.F. \& Thybo, A.K. (2001): The influence of sensory and physiochamical quality on Danish children's preferences for apples. Food Quality and Preference 12: 543-550.

Lee, J.Y., Brown, M.G. \& Seale, J.L. (1992): Demand relationships among fresh fruit and juices in Canada. Rev. Agric. Econ. 14: 255-262.

Market Review (1996): UK Fruit and Vegetable Market Review 1995-1996. Fresh Fruit and Vegetable Information Bureau, London.

McCracken, V.A., Maier, B., Boylston, T. \& Worley, T. (1994): Development of a scheme to evaluate consumer apple variety preferences. J. Food Distr. Res. 56-63.

Moskowitz, H.R. (1994): Children versus adults (In: Moskowitz, H.R. (ed.), Food concepts and products, Just-in-Time Development) (pp. 293-331). Trumbull, Connecticut, USA: Food \& Nutrition Press, Inc.

Nu, C.T., MacLeod, P. \& Barthelemy, J. (1996): Effects of age and gender on adolescents' food habits and preferences. Food Quality and Preference 7: 251-262.

Patterson, P.M. \& Richards, T.J. (2000): Newspaper advertisement characteristics and consumer preferences for apples: a MIMIC model approach. Agrobusiness 16: 159-177.

Péneau, S., Hoehn, E., Roth, H.-R., Escher, F. \& Nuessli, J. (2006): Importance and consumer perception of freshness of apples. Food Quality and Preference. 17: 9-19.

Poelman, A. (2008): Consumer tastes differ. Australian Fruitgower 2(2): 18-19.
Ragaert, P., Verbeke, W., Devlieghere, F. \& Debevere, J. (2004): Consumer perception and choice of minimally processed vegetables and packaged fruits. Food Quality and Preference. 15(3): 259-270.

Racskó, J. (2007): International consumer preference for apple cultivars. Lippay János - Ormos Imre - Vass Károly Scientific Symposium. Budapest, Hungary. November 7-8, 2007. Abstracts, 172-173. (In Hungarian)

Racskó, J., Soltész, M., Szabó, Z., Fári, M. \& Nyéki, J. (2007): Consumer preference for selected apple varieties grown in the temperate zone, subtropics and tropics. 8th International Symposium of Temperate Zone Fruits in the Tropics and Subtropics. October 21-25, 2007, Fraiburgo (SC), Brazil. Abstracts, 33. p.

Redgwell, R.J. \& Fischer, M. (2002): Fruit texture, cell wall metabolism and consumer perceptions (In: Knee, M. (ed.): Fruit quality and its biological basis.) Sheffield Academic Press, Sheffield, pp. 46-88.

Richards, T.J. (1999): Dynamic model of fresh fruit promotion: a household production approach. Am. J. Agric. Econ. 81: 195-211.

Richards, T.J. \& Patterson, P.M. (2000): New varieties and the returns to commodity promotion: the case of Fuji apples. Agric. Res. Econ. Rev. 29: 10-23.

Schafer, E., Schafer, R.B., Bultena, G.L. \& Hoiberg, E.O. (1993): Safety of the US Food Supply: Consumer concerns vs. Behavior. J. Consumer Studies and Home Econ. 17: 137-144.

Stanton, R. (2008): Encouraging fruit consumption. Australian Fruitgrower. 2 (2): 12-13.

Stow, J. (1995): Quality measurements of apples. Postharvest News and Information. 6: 32-33.

Wandel, M. (1994): Consumer concern and behavior regarding food and health in Norway. J. Consumer Studies and Home Econ. 18: 203-215.

Wandel, M. \& Bugge, A. (1997): Environmental concern in consumer evaluation of food quality. Food Quality and Preferences. 8 (1): 19-26.

Zandstra, E.H. \& de Graff, C. (1998): Sensorlpy perception and pleasantness of orange beverages from childhood to old age. Food Quality and Preference. 9: 5-12.

Zind, T. (1989): Fresh trends ' 90 - a profile of fresh produce consumers. Packer Focus 96 (54): 37, In: Shewfelt, R.L. (1990): Quality of fruits and vegetables. Food Technology. 44 (6): 99-106. 